\title{
Reflections on Teaching Literacy to Young Bilingual EFL Learners
}

\author{
Niloufar Shahmirzadi \\ Candidate in Applied Linguistics \\ Islamic Azad University, Tehran, Iran
}

\begin{abstract}
Concerning the new field of second language learning, literacy as the outstanding subfield in SLA has influenced teaching and assessment. However, literacy programme in the L1 along with second or foreign languages requires further research. According to Swain [1] "... heritage language use without literacy has little effect”. Thus, the current study aims to focus on learning Farsi as the L1, and English as the foreign language of 15 young first grade elementary participants so as to have thick description. In order to observe the rate of success in each language, three features which are number of pauses [2], false starts and repetitions [3] were analysed to tackle the first research question. The results depict no relationship between these three features in pairs except false starts and repetitions but it is not so strong. Considering the second research question among three stated features no one received high mean score, which is noticeable, since their language has not been fossilized. To sum up, the relative contribution of per feature in each language reveals more insights into the nature of each and all languages in order to scaffold the participants to develop firstly literacy in $L 1$, and then to promote the foreign language.
\end{abstract}

\section{Introduction}

According to Adams [4]; Balmuth [5]; Chall [6]; Huey [7] one of heated debates in education has been primary literacy instruction in recent century. In the past, the task of effectively teaching reading skills received so much attention during the first few years of schooling programme; however, there were problems from some researchers' point of view in which the very earlier failure to develop basic reading abilities might lead to later academic, economic, and social-emotional difficulties [8] [9] [10] [11]. As a result, by growing interests in development of models and theories some models such as sight word, phonics and linguistic approaches have been proposed to explain how children could learn to read. In line with that skillbased approaches emphasised the importance of "breaking the code" [12] [13] [14] [15] of written language. Researchers believed that children need to be taught explicitly to read; especially, decoding so as to be able to become proficient readers [4] [12] [16] Therefore, this strong foundation in the first language can help students to develop mental flexibility and problem solving skills which lead into making the learning of second or third languages easier.

According to several studies, proficiency in two or more languages aids metalinguistic awareness, and on the other hand the process of language acquisition in L1 has reached the proficiency in two or more languages [17] [18] [19]. "This is precisely what makes the difference between an "expert" who is master in L1 literacy and then moves to learn second or third language and a "novice" learner who is not perfectly literate in L1 [20]." It is justified by the fact that bilingualism adds awareness to a child compared to monolingual learners, and through learning more strategies bilinguals require putting less effort to achieve success in the process of learning a new language.

\section{Importance of Literacy Studies}

"Reading in and of itself is almost powerful enough to result in language acquisition [21]." Concerning the outcome of the majority of studies, L1 literacy aids in L2 acquisition.

His theory promoted by the fact that L1 literacy is the foundation of language education in different areas; for example, as a tool for accentuating repertoire of vocabulary, reading, writing, spelling and comprehending which enhances readers' language awareness and proficiency. Moreover, L1 literacy "develops an understanding of what reading and writing are for or perception of its function", and "provides resources to employ, as they move into second language reading and writing [22] [23]. For example, encouraging multilitercy in some schools like Belgium, Switzerland and Sweden needs a strong foundation in the native language [24]. As a result, without literacy awareness, assessing could not to be fulfilled properly.

Regarding the considerable importance of reading in literacy awareness and evaluation, fluency has to be taken into account.

\section{Defining Fluency}

Fluency refers to general language proficiency; particularly, characterised by perceptions of ease, eloquence, and smoothness of speech or writing [25] [26] [27] [28] [29] [30]. Successful language performance in literacy has often been characterised 
as reading at normal rate without interruption resulting in fluency.

\section{Fluency in SLA research}

The aim of the present study was to investigate the growth of Farsi as the first language and English as the foreign language on literacy programme with respect to number of pauses, false starts and repetitions of participants with the same level of language proficiency. In order to analyse the rate of success or failure in participants' performance, a model was needed. In this study, the model particularly was in accordance with new methods of evaluation and teaching [31] [32] [33] [34]. Although a number of measurements were used, the necessary criteria based on the purpose of the present study were temporal variables and hesitation phenomena as the two sub categorisation in analysing fluency. In what follows, the classifications and the method of estimating these criteria were presented.

For measuring fluency facets, number of pauses as the subcategorisation of temporal variable, false starts as the subcategorisation of hesitation phenomena, and repetitions were applied (adapted from Ellis \& Barkhuizen [35]. In order to employ these three facets, the descriptions of measurements were concerned. For number of pauses: the total number of filled and unfilled pauses for each speaker [2], false starts: utterances/sentences that is not complete. They may or may not be followed by reformulation [3], and for repetitions: words, phrases or clauses that are repeated without any modification whatsoever [3] were counted.

\section{Research Questions}

Since this article attempts to study literacy programme in two languages that is Farsi and English, as the First and Foreign languages at the same time, the following research questions are as follows:

RQ1: What are the relative contributions of pauses, false starts and repetitions in print literacy of the participants?

RQ2: Will two groups (Farsi as the first language and English as the foreign language) differ in their choice of (number of pauses, false starts and repetitions) in contextual usage measure?

\section{Materials and Method}

Since the purpose of the present research was to study the literacy programme in two languages at the same time, every step was taken into consideration throughout the study.
As for the quantitative nature of the study, a series of measures was taken in order to analyse the collected sample and feed the raw data into SPSS so as to provide tangible and reliable result. In the meanwhile, a within subject design was measured in which the same group as the independent variable experience different treatment that is learning Farsi and English to conclude in which language participants could learn easier and what features they tend to use in high frequency in the process of literacy programme. In what follows, the details of doing study were provided in numerical values.

\subsection{Participants}

The participants of the present study were 15 random sampled male with the age range between six to seven years old. They entered in the first grade of non-profit primary school that had received no previous academic knowledge of Farsi or English before that, but received one year of educational experience in kindergarten. As the educational curriculum programme, all the students were supposed to attend Farsi as their first language, and English as their foreign language classes. Moreover, the performance of 15 random sampled participants were analysed in order to have thick description. They were also given IDs to have saturated and in depth analysis in results of the study.

\subsection{Procedure}

During the first year of schooling, from October to June, participants took part literacy programmed in their L1; they were also programmed to take English language course. All participants were at the same level of proficiency in both Farsi and English. They were scheduled to learn Farsi as their first language and English as their foreign language in the first year of schooling. The national material that is "Farsi Bekhanim" [36] for teaching Farsi was used, and as for English material "Starters" [37] was applied. The timetable of teaching Farsi and English was one hour and half in five days per week in the morning or at noon interchangeably for each language. In both language classes, participants were supposed to learn how to read as the focus of their print literacy programme.

\subsection{Data collection}

The collected corpus of the present study composed of 15 first grade elementary school language learners' performance. Participants were all zero beginners; therefore, they had all the same level of proficiency. After nine months of literacy programme, the researcher recoded the oral performance of participants in both Farsi and English. In the present study in order to control the 
internal validity threat that is diffusion, a passage was developed by Farsi and English teachers in accordance with the taught contents for administering the test. And for checking the interrater reliability of the passage, the researcher separately asked two other Farsi and English teachers of the very school to confirm whether the content and difficulty level of the passages were in line with the course books. Meanwhile, all data collection procedure was done under the supervision of Farsi and English experienced language teachers. It is worth mentioning that literacy in Farsi was scheduled for all the students; however, it was not mandatory for all students to learn English as a foreign language from the first year of schooling. Regarding the participants of the present study, it is worth noting that they were quite willing to take English language course along with Farsi language in the first year of schooling.

\subsection{Test administration task}

Considering the assigned national literacy curriculum, students were supposed to study Farsi book as the mother tongue material. Also, English material was scheduled by the school English Language department to be taught. As for early proficiency level, all participants did not have any literacy of reading; therefore, they were planned to learn Farsi and English during nine months from October until June. Then, participants were expected to sit for the final examination session. Two tests were administered in two different timetables. The participants were supposed to read a passage in Farsi and English. The duration of taking the test varied since it had gone under investigation to see their level of proficiency in literacy.

\subsection{Test administration procedures}

As mentioned earlier after nine months of starting literacy programme in both Farsi and English, the participants were supposed to take a test, which was reading a passage in Farsi and English. Therefore, participants required to be provided by some instructions in order to do the task independently. The rationale for administering the test after nine months was that it was in accordance with the schedule of educational ministry to evaluate the threshold level of participants' literacy at the end of the educational year.

\section{Results}

After collecting Farsi and English samples at the end of the course, the researcher identified the recorded samples by cardinal numbers, then the samples were analysed based on the three features which were provided above.
Table 1 shows participants' number of occurrence of each feature in both Farsi and English, orderly.

Table 1. Raw data

\begin{tabular}{|c|c|c|c|c|c|c|}
\hline \multirow{2}{*}{$\begin{array}{l}\text { Candidates } \\
\text { (Cardinal } \\
\text { Numbers) }\end{array}$} & \multicolumn{3}{|c|}{ Farsi Language } & \multicolumn{3}{|c|}{ English Language } \\
\hline & $\begin{array}{c}\text { No of } \\
\text { Pauses }\end{array}$ & $\begin{array}{l}\text { No of } \\
\text { False } \\
\text { Starts }\end{array}$ & $\begin{array}{l}\text { No of } \\
\text { Repet } \\
\text { itions }\end{array}$ & $\begin{array}{c}\text { No of } \\
\text { Pauses }\end{array}$ & $\begin{array}{l}\text { No of } \\
\text { False } \\
\text { Starts }\end{array}$ & $\begin{array}{c}\text { No of } \\
\text { Repeti } \\
\text { tions }\end{array}$ \\
\hline 1 & 1 & 3 & 0 & 0 & 24 & 3 \\
\hline 2 & 1 & 2 & 10 & 1 & 10 & 5 \\
\hline 3 & 1 & 5 & 10 & 0 & 17 & 45 \\
\hline 4 & 2 & 0 & 3 & 4 & 11 & 11 \\
\hline 5 & 1 & 0 & 4 & 1 & 5 & 0 \\
\hline 6 & 0 & 0 & 0 & 0 & 14 & 0 \\
\hline 7 & 0 & 3 & 2 & 0 & 15 & 6 \\
\hline 8 & 2 & 5 & 0 & 9 & 18 & 5 \\
\hline 9 & 0 & 3 & 0 & 0 & 9 & 0 \\
\hline 10 & 0 & 4 & 1 & 0 & 13 & 11 \\
\hline 11 & 3 & 26 & 10 & 1 & 24 & 8 \\
\hline 12 & 0 & 0 & 1 & 0 & 10 & 0 \\
\hline 13 & 0 & 2 & 6 & 0 & 23 & 16 \\
\hline 14 & 0 & 0 & 6 & 0 & 28 & 18 \\
\hline 15 & 0 & 5 & 7 & 0 & 12 & 8 \\
\hline
\end{tabular}

Also, Table 2 depicts descriptive statistics of number of pauses, false starts, and repetitions.

Table 2. Descriptive statistics

\begin{tabular}{|c|c|c|c|c|c|}
\hline & & \multicolumn{2}{|c|}{$\begin{array}{c}\text { Farsi } \\
\text { Language }\end{array}$} & \multicolumn{2}{c|}{$\begin{array}{c}\text { English } \\
\text { Language }\end{array}$} \\
\hline & $\begin{array}{c}\text { No of } \\
\text { Participants }\end{array}$ & Mean & $\begin{array}{c}\text { Std. } \\
\text { Deviation }\end{array}$ & Mean & $\begin{array}{c}\text { Std. } \\
\text { Deviation }\end{array}$ \\
\hline Pauses & 15 & 0.73 & 0.96 & 1.06 & 2.43 \\
\hline False Starts & 15 & 3.86 & 6.42 & 15.53 & 6.65 \\
\hline Repetitions & 15 & 4.00 & 3.89 & 9.06 & 11.45 \\
\hline
\end{tabular}

As Table 2 shows, all participants received low mean scores in both Farsi and English languages. However, the number of repetitions in Farsi and False starts in English were a little high.

After entering the data into SPSS correctly and calculating mean scores and standard deviations, it was necessary to run SPSS programme to measure correlation. Therefore, Spearman's rank-order correlation was calculated between pauses, false starts and repetitions. Table 3 presents the results in Farsi language as follows.

Table 3. Non-parametric correlations in Farsi

\begin{tabular}{|l|c|c|c|}
\hline & $\begin{array}{l}\text { Pauses- } \\
\text { False } \\
\text { Starts }\end{array}$ & $\begin{array}{l}\text { Pauses- } \\
\text { Repetitions }\end{array}$ & $\begin{array}{l}\text { False Starts- } \\
\text { Repetitions }\end{array}$ \\
\hline Sig.(2-tailed) & 0.305 & 0.404 & 0.466 \\
\hline $\begin{array}{l}\text { Spearman's rho } \\
\text { P }<.05\end{array}$ & 0.28 & 0.23 & 0.20 \\
\hline
\end{tabular}


The results obtained indicate that no relationship could be observed between the three groups in pairs in Farsi. And Table 4 depicts the findings of correlation in English language.

Table 4. Non-parametric correlations in English

\begin{tabular}{|l|c|c|c|}
\hline & $\begin{array}{l}\text { Pauses- } \\
\text { False } \\
\text { Starts }\end{array}$ & $\begin{array}{l}\text { Pauses- } \\
\text { Repetitions }\end{array}$ & $\begin{array}{l}\text { False Starts- } \\
\text { Repetitions }\end{array}$ \\
\hline Sig. (2-tailed) & 0.583 & 0.756 & 0.038 \\
\hline Spearman's rho & -0.15 & -0.08 & 0.54 \\
\hline P $<.05$ & & & \\
\hline
\end{tabular}

As Table 4 shows there was no correlation between pauses and false starts; pauses and repetitions in pairs. Interestingly enough there was a slight relationship between false starts and repetitions in English, but it was not so strong.

Although most of the participants benefited from knowledge of phonics, they endured lack of awareness on spelling. Furthermore, age factor should not be neglected since young learners still were not mature enough to acquire and distinguish concurrently the differences of two languages without "noticing, discovering rules, restructuring and experimentation [38]."

\section{Discussion and Conclusions}

One of the widely debated topics in education literature is teaching literacy in first language along with teaching English as a foreign language. Several studied have been conducted to prove the fact that "even when two languages use different writing system, readers could apply some visual, cognitive or linguistic strategies of learning their first language to reading the second language [1]." Concerning the purpose of the present study which is teaching literacy to bilingual learners and relative contribution of pauses, false starts and repetitions saturated sample was employed to gain a deeper thick description.

Regarding the purpose of the present study and in order to tackle the first research question, there is no relationship between pauses, false starts and repetitions. Also, lack of being proficient enough in L1 literacy had a negative impact on learning a foreign language. Therefore, successful L1 achievement contributed to critical L1 literacy which directs not to burden unnecessary budgeting for undertaking the task of foreign language literacy. Also, Farsi language writing system is completely different from English, which results in suffering from two different writing systems, and lack of literacy in their native language lead to not having the same academic advantage, as well.

Moreover as for the second research question, different measures that is (number of pauses, false starts and repetitions) do not contribute to better L1 or foreign language literacy. On the whole, participants enjoyed low mean scores in both Farsi and English; therefore, the chance of fossilisation was hopefully low.

To sum up, participants did not reach the threshold level of proficiency or "language awareness" [1] since they did not expose to various environments such as books or newspaper. As a result, it is suggested to teach literacy in L1 and later foreign language. Interestingly enough, conducted previous studies have shown that "longitudinal or cross sectional studies which paid attention to different linguistic abilities, different groups with variety of age range [39]" emphasise the remarkable importance of metalinguistic awareness on language acquisition. And, Swain et al.'s study [1] also did isolate "biliterates from bilinguals" that is developing metalinguistic awareness in first and subsequent languages help to produce language. According to "Descriptions of Reading Skill in Second Language Acquisition and Literacy Development" some tasks to be exercised to manage thorough literacy and second language development (Adapted from English as a Second Language and English Literacy Development, Ministry of Education [40]).

Stage A1, Grade1-3: Students read and comprehend simple written English. They recognize the alphabet in print; read pictures and use picture clues; participate in shared reading activities, choral reading, and rehearsed reading in a small group; know the direction of English print; select appropriate reading materials, with assistance; recognize familiar words and repeated phrases in plays, poems, stories, and environmental print; begin to use phonetic and context clues and sight recognition to understand simple texts (e.g., pattern books, charts, stories, songs, chants, rhymes (p. 30).

Concerning stage A1, to facilitate language learning or better to name biliterate, program planners should ensure that language is used in natural and practical contexts. Mistakes are also accepted to diminish so as young learners do not experience pressure of learning in first or foreign language (Ministry of Education [38]). Moreover, maintaining of students' monitoring depends on the vitality of their needs on local circumstances which may gradually appear to be completely integrated in the programme.

All in all, it is recommended to duplicate the present study in second year of elementary school, and compare the results with the present study to find whether passing a year of merely literacy programme aids participants to learn foreign language easier and better. Another direction for research is to compare the result of concurrent learning first language besides second and third language; especially, in 
multilingual societies in which English is considered as a foreign language. And finally, a study might be design to investigate the heterogeneous group of participants.

\section{References}

[1] Swain, M., Lapkin, S., Rowen, N. \& Hart, D. "The role of mother tongue literacy in third language learning". Language, Culture, and Curriculum. 1990. 3.1, 65-81.

[2] Robinson, P., S. Ting, \& J. Unwin. "Investigating second language task complexity.”RELC Journal. 1995. $25,62-79$.

[3] Skehan, P., \& P. Foster. "The influence of task structure and processing conditions on native retelling." Language Learning. 1999. 49, 931-120.

[4] Adams, M. J. Beginning to read: Thinking and Learning about Print. Cambridge, MA: MIT Press. 1990.

[5] Balmuth, M. The Roots of Phonics. New York: Teachers College Press. 1982.

[6] Chall, J. S. Learning to Read: The Great Debate (updated ed.). New York: McGraw Hill. 1983a.

[7] Huey, E. Psychology and Pedagogy of Reading. New York: Macmillan. 1908.

[8] Athey, I. Reading Research in the Affective Domain. In H. Singer \& R. Ruddell (Eds.), Theoretical Models and Processes of Reading (2nd ed., 352-380). Newark, DE: International Reading Association. 1976.

[9] Dunwant, N. The Relationship between Learning Disabilities and Juvenile Delinquency. Williamsburg, VA: National Center for State Courts. 1982.

[10] Lloyd, D. "Prediction of school failure from thirdgrade data." Educational and Psychological Measurement. 1978. 38, 1193-1200.

[11] Snider, V. E., \& Tarver, S. G. "The effect of early reading failure on acquisition of knowledge among students with learning disabilities." Journal of Learning Disabilities. 1987. 20, 351-356.

[12] Chall, J. S. Stages of Reading Development. New York: McGraw Hill. 1983b.

[13] Flesch, R. Why Johnny Can't Read. New York: Harper \& Row. 1955.

[14] Gough, P. B. "One second of reading." Visible Language. 1972. 6, 291-320.

[15] Gunning, T. G. "Word building: A strategic approach to the teaching of phonics."Reading Teacher. 1995. 48, 484-488.

[16] Henry, M. K. "The role of decoding in reading research and instruction." Reading and Writing: An Interdisciplinary Journal. 1993. 5, 105-112.
[17] Ringbom, H. The Role of the First Language in Foreign Language Learning. Clevedon: Multilingual Matters. 1987.

[18] Cenoz, J. \& Valencia, J. "Additive trilingualism: Evidence from the Basque Country". Applied Psycholinguistics. 1994. 15, 195-207.

[19] Lasagabaster, D. Learning English as an L3. ITL Review of Applied Linguistics. 1998. 121-122, 51-84.

[20] McLaughlin, B. \& Nayak, N. Processing a New Language: Does Knowing other Languages Make a Difference? In H. W. Dechert \& M. Raupach (Eds.), Interlingual Processes (5-16). Tubingen: Gunter Narr. 1989.

[21] Krashen, S. The Power of Reading. Insights from the Research. Englewood, Colorado: Libraries Unlimited, Inc. 1993.

[22] Hudelson, S. 'The role of native language literacy in the education of language minority children". Language Arts. 1987. 64, 826-41.

[23] Tokuhama-Espinosa., T. Raising Multilingual children: Foreign Langauge Acquisition and Children. Westport, CT: Bergin \& Garvey. 2001.

[24] Wojtowicz, D. "The role of literacy in second and third language acquisition". Proceedings of the CATESOL State Conference. 2006.

[25] Lennon, P. "Investigating fluency in EFL: A quantitative approach." Language Learning. 1990. 40.3, 387-417.

[26] Chambers, F. "What do we mean by fluency?" System. 1997. 25.4, 535-44.

[27] Guillot, M. N. Fluency and its Teaching. Philadelphia: Multilingual Matters. 1999.

[28] Freed, B. Is fluency, like beauty, the eyes, of the beholder? In H. Riggenbach (ed.), Perspectives on Fluency 243-265. Michigan: The University of Michigan Press. 2000 .

[29] Koponen, M., \& H. Riggenbach. Overview: Varying perspectives on fluency. In H. Riggenbach, Perspectives on Fluency 5-24. Ann Arbor, MI: University of Michigan Press. 2000.

[30] Hilton, H. "The link between vocabulary knowledge and spoken L2 Fluency." Language Learning Journal. 2008. 36.2, 153-66.

[31] Anderson, J. R. "Automaticity and the ACT theory." American Journal of Psychology. 1992. 105.2, 165-180.

[32] Anderson, J. R, \& J. M. Fincham. "Acquisition of procedural skills from examples."Journal of Experimental Psychology: Learning, Memory and Cognition. 1994. 20.6, 1322-1340. 
[33] DeKeyser, R. M. Automaticity and Automatisation. In P. Robinson (Ed.), Cognition and Second Language Instruction 125-151. Cambridge: Cambridge University Press. 2001.

[34] LaBerge, D., \& S. J. Samuels. "Toward a theory of automatic information processing in reading." Cognitive Psychology. 1974. 6, 293-323.

[35] Ellis, R., \& G. Barkhuizen. Analysing Learner Language. New York: Oxford University Press. 2005.

[36] Ministry of Education. Farsi Bekhanim. Ministry of Education Publication. 2014.

[37] Saxby, K. Cambridge English: Starters (YLE Starters). Cambridge University Press. 2011.

[38] Richards, J., C. \& Renandya, W., A. Methodology in Language Teaching: An Anthology of Current Practice. Cambridge University Press. 2002.

[39] Wagner, D. A., Spratt, J. E., \& Ezzaki, A. "Does learning to read in a second language always put the child at a disadvantage? Some counterevidence from Morocco". Applied Psycholinguistics 1989. 10, 31-48.

[40] Ministry of Education. English as a Second Language and English Literacy Development. A Resource Guide. Queen's Printer for Ontario. 2001. 